\title{
Early modern medical interaction
}

\author{
Kalle Kananoja: Healing knowledge in Atlantic Africa. Medical \\ encounters, 1500-1850. Cambridge: Cambridge University Press, \\ 2021, xii + 258 pp, $£ 75$ HB
}

\section{Adam Jones $^{1}$}

Accepted: 26 October 2021 / Published online: 10 November 2021

(c) The Author(s) 2021

The cynical notions that circulated among Europeans in the nineteenth and twentieth centuries concerning African medical practices are well known. But it is seldom recognised that such cultural arrogance was by and large a product of the Enlightenment, whereas in the Early Modern period what this book calls 'cross-cultural medical interaction', although not omnipresent, was potentially intense.

Despite the broad title, the study focuses mainly upon the 'contact zone' of WestCentral Africa, complemented by two (out of seven) chapters on the Gold Coast and Sierra Leone. The author makes good use of the primary sources, including a substantial amount of unpublished material from the Portuguese and Angolan archives, although he does overlook a few early Dutch sources. He is well aware of the limitations and pitfalls of these sources, especially for a historian searching for evidence of innovation rather than assuming that all indigenous knowledge was 'traditional'. I like the way he handles 'silences' in the sources, for instance with regard to herbalism or the cause of high mortality rates, and he has a good eye for detecting when a particular term entered popular discourse. Relevant anthropological work is taken into account, as is the linguistic evidence.

Kananoja does everything possible to uncover African 'voices' in these sources. The richest possibilities for doing so seem to lie in the seventeenth- and eighteenth century records of the Lisbon Inquisition's Angola commissioners. He draws interesting insights from this material, mainly relating to a combination of harming (through witchcraft) and healing (through spirit possession), two approaches often closely linked in African thought. He argues convincingly that there was much 'common ground between precolonial West-Central African and early modern European concepts of illness, health and healing' (33). This common ground seems to have made it easier for both sides - and more particularly for cultural brokers- to

Adam Jones

jones@uni-leipzig.de

1 Universität Leipzig, Leipzig, Germany 
experiment, borrowing ideas, materials and rituals not only from one another, but also from Asia and the Americas.

An important finding is that while the notion of humoral imbalance was still of importance in European medical thinking well into the eighteenth century, it played only a minor role in the medical practice of Europeans in Africa, apart from the persistence of bloodletting. Moreover, Kananoja shows that, contrary to what one might assume, Europeans in Africa 'regarded their bodies as inherently similar to African bodies' (159). He has interesting things to say about how melancholy was thought to affect both Europeans and Africans in Central Africa. One poignant example is the recommendation made by the chief physician of Portugal's Angola colony that on slave ships melancholic slaves 'should be obliged to smile and sing when they can' (177). Kananoja discusses at some length the emergence in the context of the Atlantic slave trade of banzo, a mental affliction affecting both Africans and Europeans, which he identifies - again with reference to the dimly perceptible African voicesas 'longing for something that the individual could not reach' (180).

As far as the Europeans are concerned, Kananoja succeeds in demonstrating that by the late eighteenth century — and in some cases much earlier-not only the Portuguese, but a significant number of Dutchmen, French, Danes and Englishmen were interested in African medical knowledge as well, and that some of them documented or applied it.

The book provides, in tabular form, intriguing information extracted systematically from primary sources, for instance there are tables of:

- items confiscated from three African healers and the spirits they pertained to,

- the functions of healing specialists in the Kongo region,

- imports of antimalarial drugs in Luanda,

- diagnoses attached to the leave requests of soldiers in Angola,

- herbal remedies recorded by a Portuguese officer,

- medicines imported to Luanda from overseas.

In some cases, the value of these lists lies in the quantitative data, such as the numbers of syringes and cupping horns imported into Africa; in others, the contemporary European observations on the efficacy or inefficacy of particular African medicines are what is most revealing.

While Kananoja's arguments concerning the 'mobility of people, knowledge and materials' and on cross-cultural interaction, aided in the eighteenth century by the employment of cultural brokers, seem largely convincing, I was surprised that he does not engage with the influential article of Wyatt MacGaffey about 'dialogues of the deaf' between Europeans and Africans in precisely this region and period (MacGaffey 1994). One might argue that each side-Europeans and Africans-operated, as MacGaffey puts it, on a 'false but workable presumption that analogous concepts on the other side were essentially identical with its own'. While Europeans in the contact zone were developing what became a theory of African fetish-worship, Congolese found it helpful to classify Europeans as simbi spirits, and although neither of these approaches bore much relation to empirical fact, they guided interaction between the two sides for centuries. The tensions underlying such a "working 
misunderstanding' are hinted at in some of the vignettes Kananoja offers us, for instance involving African Catholics who acknowledged the healing power of takula wood while remaining aware 'that the healing ritual contained suspicious elements' (3). Kananoja's decision not to overplay the misunderstandings and to emphasise instead the commonalities is legitimate; yet his own material occasionally seems to point in a different direction.

Nonetheless, this book marks a significant step forward in our understanding of how the production of knowledge - in the medical field as well as in others, such as geography_depended upon interaction between European men and African men and women, as well as upon the mobility of these people. This book represents a piece of solid and unpretentious research, and should provide much food for thought concerning African-European relations in this period.

Funding Open Access funding enabled and organized by Projekt DEAL.

Open Access This article is licensed under a Creative Commons Attribution 4.0 International License, which permits use, sharing, adaptation, distribution and reproduction in any medium or format, as long as you give appropriate credit to the original author(s) and the source, provide a link to the Creative Commons licence, and indicate if changes were made. The images or other third party material in this article are included in the article's Creative Commons licence, unless indicated otherwise in a credit line to the material. If material is not included in the article's Creative Commons licence and your intended use is not permitted by statutory regulation or exceeds the permitted use, you will need to obtain permission directly from the copyright holder. To view a copy of this licence, visit http://creativecommons.org/licen ses/by/4.0/.

\section{Reference}

MacGaffey, Wyatt. 1994. Dialogues of the deaf: Europeans on the Atlantic coast of Africa. In Implicit Understandings: Observing, reporting, and reflecting on the encounters between Europeans and other peoples in the early modern era, ed. Stuart B. Schwartz, 249-267. Cambridge: Cambridge University Press.

Publisher's Note Springer Nature remains neutral with regard to jurisdictional claims in published maps and institutional affiliations. 